\title{
Procedee translingvistice în conturarea portretului bi(multi)lingv din romanul Moarte în ținutul secuilor, de Caius Dobrescu
}

\author{
Erika-Mária Tódor ${ }^{\star}$ \\ Facultatea de Științe Economice, Socio-Umane și Inginerești, Universitatea Sapientia, Piața Libertății 1, \\ 530104 Miercurea Ciuc, România
}

\begin{abstract}
Despre articol
Istoric:

Primit 18 iunie 2019

Acceptat 16 iulie 2019

Publicat 7 noiembrie 2019

Cuvinte-cheie:

discurs translingvistic comunicare transculturală profilul bi(multilingv) arta cuvîntului

Rezumat

În prezentarea de față mă voi opri asupra a două concepte, aparţinînd unor domenii înrudite din cadrul științelor filologice (translingvistica și portretul personajelor) și voi urmări cum anume se individualizează o abordare lingvistică în contextul artei cuvintului.

Situațiile translingvistice de comunicare sînt caracteristicile specifice ale conduitei verbale bi- sau multilingve și rezultă din abordarea holistică a repertoriului lingvistic al vorbitorului. Conceptul desemnează modul complex și dinamic de exprimare a vorbitorului, în care se activează resursele lingvistice adecvate contextului, depăşind limitele limbilor vorbite. În analiza constituirii de sens din cadrul operei lecturate, voi încerca să urmăresc cum anume un fenomen lingvistic capătă actualizare prin arta cuvîntului ca mijloc de caracterizare a personajelor şi de creare a culorii locale. În demersul euristic al investigației, după clarificarea conceptelor-cheie, voi urmări principalele forme ale constituirii spațiului translingvistic pe baza analizei corpusului elaborat după romanul avut în vedere.
\end{abstract}

\section{Spațiul translingvistic și comunicarea literară}

Conceptul de situații translingvistice de comunicare este un termen relativ nou în domeniul lingvisticii aplicate și desemnează aceea abilitate a vorbitorului bi(multi)lingv de a valorifica, în manifestarea Sinelui și a intenției sale de comunicare, întregul repertoriu lingvistic de care dispune la un moment dat, chiar cu depăşirea limitelor sistemelor lingvistice. Termenul a fost folosit inițial în domeniul pedagogiei limbii de către Cen Williams, în 1994, sub denumirea galeză de trawsieithu (Lewis et al., in Tódor et al., 2019, p. 285) pentru a desemna acele situații de dialog școlar cînd s-au activat două limbi; în cazul citat elevii au lecturat în galeză şi au scris sau au vorbit despre texte în limba engleză.

Referentul conceptului desemnat prin acest termen reprezintă o realitate socio- și psiholingvistică care l-a preocupat de mult pe specialiștii din domeniu. Din punct de vedere lingvistic, schimbarea registrelor de comunicare a căpătat de-a lungul timpului reinterpretări diferite, ceea ce se poate urmări şi prin accepțiunile conturate termenului de-a lungul traiectoriei sale diacronice. De numele lui Ferguson (1959) se leagă prima teoretizare a acestei realități, desemnînd prin termenul de diglosie schimbările registrelor înalte (în primul rînd scrise, oficiale) și cotidiene (în primul rînd orale) ale vorbirii. Reinterpretarea acestui concept apare în scrierile lui Fishman $(1970,2000)$ lărgindu-se sfera semantică a termenului prin referire și la situațiile bilingve de comunicare, în care limbile se activează în funcție de specificul formal (oficial) şi informal al contextului de comunicare. Mai tîrziu, în literatura de specialitate se introduce termenul de schimbare de cod lingvistic sau codică, care desemnează activarea alternativă a limbilor (Holmes \& Wilson, 2017), iar această folosire combinativă poate atinge diferitele niveluri ale sistemului lingvistic (de la nivelul fonetico-fonologic, la cel sintactico-semantic), concretizindu-se la nivel intrapropozițional, interpropozițional și la nivelul discursului. Avînd la bază specificul situaţiei de comunicare, conceptul de schimbare de cod lingvistic, este interpretat în funcție de cîmpul motivațional al vorbitorului și astfel,

\footnotetext{
*Adresă de corespondență: todor.erika.m@gmail.com.
} 
Erika-Mária Tódor

fenomenul se interpretează prin raportare la intenția comunicării (Bartha, 1999; Navracsics, 2000; Benő, 2008), cum ar fi: personalizarea mesajului, semnalarea schimbării temei de discuție, citarea, marcarea distanțării sau a identificării/non-identificării cu o situație dată, etc. (Tódor et al., 2019, p. 209).

Abordarea holistică a producției verbale a implicat apariția unui nou concept, răspîndit într-un timp relativ scurt ca termen generic (Wei, 2005,2018; Cenoz \& Gorter, 2017), căci percepe producția verbală în praxisul vorbirii, în raport cu deciziile lingvistice, strategiile de activare a limbilor, experințele de învăţare şi de comunicare; este o „teorie pragmatică” a limbii (Wei, 2018). Astfel, după García \& Wei (2014, p. 45) asistăm la un proces de constituire de sens, prin activarea tuturor registrelor lingvistice de care dispune individul, căci ,activarea limbilor și schimbările de cod în cazul vorbitorului bilingv sînt manifestări socio-culturale, determinate relaţional”a (Wei, 2011, p. 2). Abordarea translingvistică interpretează procesul constituirii de sens în corelație cu determinanții socio-culturali și lingvistici ai comunicării, „spațiul translingvistic fiind o experiență socială cu implicare afectivă intensă’b (Wei, 2011, 2018).

Interpretarea termenului de translingvistică ne va de încă mult timp bătăi de cap, dar la ora actuală, pe baza literaturii de specialitate se poate conchide că diferența majoră dintre cele două concepte este determinată de abordarea oferită repertoriului lingvsitic, de modul de conservare, de calitatea achiziției, de specificul reactivării stimulilor lingvistici. În Dicţionarul de lingvistică aplicată se specifică faptul că „Specialiştii consideră că situațiile translingvistice diferă de fenomenul de codică (de schimbare a codului lingvistic), deoarece acest ultim concept vizează alternarea diferitelor structuri de limbă, iar în cazul interpretării situațiilor translingvistice se porneşte de la premisa că vorbitorul dispune de un repertoriu lingvistic complex (Gorter \& Cenoz, 2015), din care îşi alege resursele lingvistice adecvate contextului, astfel aceste situații de vorbire depăşesc limitele limbilor vorbite (García \& Wei, 2014, p. 22)" (Tódor et al., 2019, p. 285). Este greu de delimitat sfera de cuprindere a termenilor de codică, respectiv de situație translingvistică, cert este că cele două concepte aparțin unor abordări teoretice diferite ale exitenței în și printre limbi, gradul de diferențiere fiind determinat de condiţii extrinsece, (cum ar fi: cadrul teoretic, ideologia, normele, statutul unei limbi etc.) și intrinsece (cum ar fi: mediul lingvistic apropiat al individului, intenția comunicării).

În lucrarea de față voi apela la termenul de translingvistică, deoarece oferă posibilitatea interpretării conduitei verbale în bipolaritatea ei. Interpretez modul de manifestare a personajelor, pe de o parte, ca manifestări ale Sinelui, ale modului de a fi în și între limbi diferite, iar, pe de altă parte, ca răspunsuri formulate la contextul socio-lingvistic și interpersonal în care sînt plasați, fiind reacții firești ale personajelor, formulate în contextul unui spațiu lingvistic specific. Aici, portretul Melindei din romanul studiat este un astfel de element reprezentativ prin strădania și preocuparea ei de a se face de înțeles. Asistăm în universul de creație oferit de opera lui Caius Dobrescu, la scene ale vorbirii spontane, cotidiene unde accentul se pune pe praxis, pe ideea de a se face de înțeles. Din această perspectivă devine interesantă modul de căutare a cuvintelor potrivite, precum și observarea strategiilor de comunicare găsite pentru rezolvarea unor situații de impas comunicațional. Pentru argumentarea bipolarităţii voi apela la ceea ce Eugen Coșeriu a reformulat din perspectiva dublei determinări astfel: „Limbajul este înțelegere a ființei, dar nu din partea unui subiect absolut, nici a individului empiric, ci din partea omului istoric care, tocmai de aceea, este în acelaşi timp o entitate socială. În acest sens, limbajul este fundamental pentru definirea omului. Pe de o parte este logos, înțelegerea ființei; pe de altă parte este logos intersubiectiv, formă și expresie a istoricității omului. Omul trăiește într-o lume lingvistică pe care o creează el însuși ca ființă istorică” (Coșeriu, 2009, p. 52). Comunicarea translingvistică este, în acelaşi timp, un mod de relaţionare verbală activat de contextul socio-lingvistic, deci o ilustrare a faptului că limba este un fenomen determinat social. Astfel, în literatura de specialitate Gumperz (1982), Gafaranga \& Torras i Calvo (2001), Canagarajah (2011), Cenoz \& Gorter (2017) susțin ideea că acest tip de decizie lingvistică îndeplinește funcția de organizare, structurare de discurs, este o strategie de monitorizare a resurselor vebale. Situațiile transling-

\footnotetext{
${ }^{a}$ „,(..) bilingual speakers language choise and codeswitching were network specific socio-cultural practices" (Wei, 2011).

'„Translanguaging space is an intense social experience and emotional investment" (Wei, 2011).
} 
vistice desemnează acele contexte de comunicare (Wei, 2005, p. 2011) care se concretizează în inserția elementelor altei limbi în vorbirea spontană, de bază. Motivația este complexă: în primul rînd pentru a susține eficiența comunicării, precizia transmiterii mesajului, dar se poate datora și lejerității activării limbilor sau nesiguranțelor în stabilirea limbii de bază a comunicării (Gafaranga \& Torras i Calvo, 2001).

Abordările mai sus prezentate, vizează perspective teoretice diferite, complementare asupra conceptului care oferă posibilitatea unor reinterpretări funcționale ale conduitei verbale. Această manieră de percepere a vorbitorului implică, de asemenea, interpretarea manifestărilor verbale drept texte aisberg, căci ele capătă prezențe prin motivațiile, deciziile vorbitorului. Vorbitorul nu poate fi înțeles decît relațional, participativ, activ și reactiv la stimulii exteriori.

Comunicarea literară diferă de cea cotidiană prin faptul că aceasta capătă valențe interpretative complexe. Diferența majoră este asigurată tocmai de regulile complementare, proprii sistemului creației literare (Corti, 1981, p. 82). Autorul unei opere literare poate produce devieri, transformări, rupturi individuale prin care se conturează un sistem semiologic cultural specific. În comunicarea literară, raportul dintre codul primar sau sensul de suprafață și sensurile ascunse capătă altă configurație, în favoarea sensurilor subiacente (Corti, 1981). Cornea (1998) remarcă ideea că de fapt codurile literare conțin un număr indefinit de simboluri, iar acestea devin doar parțial explicite. Textul literar reprezintă o materie vie în țesătura căreia artistul se mişcă după o lege individuală, prin care oferă una dintre direcțiile posibile în care se pot actualiza virtualitățile limbii (Corti, 1981), conturînd astfel semantica secundară a textului.

În analiza textului lui Caius Dobrescu, problematica translingvisticii se plasează tocmai la nivelul semnaticii secundare, căci în acest caz codul idiolectal al cărții, apare ca mijloc de caracterizare a personajelor și de creare a culorii locale. Cititorul obişnuit cu mijloacele consacrate de caracterizare și de creare a culorii locale (prin arhaisme, regionalisme sau sociolecte), în mod cert va fi surprins de configurația spațiului lingvistic pe care îl va regăsi prin lectura romanului Moarte în ținutul secuilor, de Caius Dobrescu. În această scriere, limbile și complementaritatea lor devin într-un mod inedit forme de articulare a unei realități multiculturale, de re-creare a realității transculturale și reprezintă strategii de organizare a coordonatelor spaţio-temporale ale textului.

\section{Cîteva cuvinte despre carte și autor}

Caius Dobrescu (născut în anul 1966) este un poet, eseist, romanciar român, contemporan. A debutat în volumul colectiv de poezii, cu titlul Pauză de respirație, alături de Andrei Bodiu, Marius Oprea, Simona Popescu, în anul 1991.

Romanul Moarte în ținutul secuilor a apărut în anul 2017 (Crime Scene Press) și reprezintă primul din seria Vlad Lupu [romanele ulterioare sînt: Prafîn ochi (2017) și Recviem pentru nimeni (2018)]. Așa cum reiese din Argument, unde sînt prezentați protagoniștii romanului, cartea propune o întîmplare centrală (se prezintă prin intermediul personajului principal, arheologul Vlad Lupu dezgroparea unor schelete din trecut) întregită prin istorisile, narațiunile conexe, constituite pe baza temei centrale. Dincolo de acest plan narativ, cartea oferă psihologia rupturii și a încercării de reconstituire a armoniei, căci personajele romanului s-au socializat într-o societate „multilateral dezvoltată” a perioadei de dinainte de ' 98 decembrie, cu mijloacele de autoapărere bine constituite (lectura, umorul negru), iar „în inima prezentului” îşi reinterpretează propriile existențe, fără a se putea lepăda de măștile trecutului. Locul acțiunii este Brașovul și Ținutul Secuiesc. Lectura cărții ne plasează într-o lume intermediară, e o lume suspendată între memoria trecutului și interpretările prezentului, între comedia neagră și jocul absurd al măștilor. Această lume capătă articulare printr-un limbaj constituit prin articularea paralelă și complementară a limbilor.

\section{Lingvistica textuală și cadrele contextului}

Analiza de față iş̧i propune să ofere o perspectivă centrată pe lingvistica textuală, o lectură care trece dincolo de analiza transfrastică, fiind preocupată de a descrie mecanismele de funcționare ale semnelor în 
organizarea transfrastică a limbajului (Vlad, 2000), de producerea co- și contextuală de sens (Coșeriu, 2013; Dospinescu, 2008), de modul cum înglobează textul spusul și nespusul, „cuvintele” și „ne-cuvintele” (Nichita Stănescu) partea explicită și implicită, textul aisberg (Vlad, 2000). Limbajul în cazul textului studiat devine o strategie de organizare a cadrului, permițînd crearea unui univers specific de discurs, a unui sistem de semnificații care se constituie prin amestecarea sau confundarea universurilor de discursuri articulate prin limbi diferite. Din acest amestec și din aceste rupturi ale cuvintelor şi necuvintelor ${ }^{1}$ autorul ajunge la nivelul unei metasemantici, la „un joc de limbaj” obținut prin hipersemn, constituit transfrastic, translingvistic și transcultural. Autorul readuce pe scenă comunicarea din viața reală, uzul și obiceiurile de activare a limbilor, fapt pentru care depășește cadrul consacrat de normele-standard ale unui sistem lingvistic și le valorifică funcțiile artistice ale contopirii și intersectării experiențelor lingvistice și culturale diferite. Asistăm în acest text la ruptura convențiilor, căci se conturează un hipersemn ${ }^{2}$, constituit dintrun cod idiolectal specific, prin unități translingvistice. Astfel, autorul transformă funcția referențială a limbii, acordă alte valori expresive investind cu funcțiile comunicării culturale și interculturale prin care se creionează portrete, locuri, cadre, fețele diferite ale comportamentului bi(multi)lingv. Expresivitatea în acest context rezultă din valorificarea vitalităţii îmbinărilor translingvistice. Unităţile translingvistice apar ca mărci ale unei realități spațio-temporale și ca expresii ale întrepătrunderii culturale.

Arhitectura textului studiat înglobează structura de suprafaţă a operei, prin prezentarea evenimentelor, întîlnirilor, căutărilor şi a descoperirilor. Conținutul capătă valoare prin forma expresiei. Astfel nivelul tematic al romanului este întregit prin nivelul expresiei, structura profundă a cărții. De aici derivă principalele întrebări ale lecturii interpretative: Care sînt, în romanul analizat, principalele tehnici, modalități și procedee prin care se constituie structura profundă a operei? Care sînt principalele niveluri în conturarea portretului bilingv și bicultural? În examinarea acestui aspect, ne-am bazat pe acele 120 de situații translingvistice pe care le-am „extras” din textul romanului studiat (numărul lor este mult mai mare) pentru a constitui corpusul examinării. Aceste unități translingvistice reprezintă situaţii de comunicare pe care autorul romanului le alege pentru conturarea portretelor socializate în limbi și culturi diferite, complementare.

\section{Portretul conduitei verbale}

Un element structurant al lecturii noastre a reprezentat conceptul de portret, conturat în acest roman prin posibilitatea unei lecturii „paralele”, în sensul că prin destinele prezentate asistăm la creionarea unor portrete intrinsece, articulate într-o manieră verbală inedită. Măiestria acestei perspective interioare își spune cuvîntul atunci cînd eul desfășurat, plasat în diferite situaţii de acțiune și de comunicare se autodefinește prin experințele trecutului și ale prezentului, narațiunile eului căpătînd astfel o intertextualitate (despre care risc să spun că în absența lecturilor anterioare cititorul poate rămîne la nivelul lecturii inocente).

Pe planul realizării concrete a portretelor distingem următoarele niveluri fundamentale, prezentate sintetic în tabelul de mai jos. Distingem A) un nivel textual intercultural (unde prin cultură înțeleg pe cea dobîndită prin lectură) și un B) nivel al interdiscursului, concretizat în întîlnirea textelor și experiențelor de lectură trecute și actualizate. C) Cea de a treia dimensiune a portretului este dimensiunea translingvistică, adică situațiile de comunicare caracterizate prin diversele forme ale întrepătrunderilor interlingvistice. Stilul romanului ilustrază o intertextualitate articulată firesc, ludic. Iată cîteva exemple ilustrative: „Monty Pyton-ul braşovean” (9); „e clar, ca pe orice Scufiță Roșie, te atrage în primul rînd lupu” (18); „...Dacă îmi spui să aduc la suprafață tot ce-mi amintesc mai repede, așa pe sofa de psibanalist...” (9); „Eu însă, draga mea, am să-ți vorbesc în stilul direct și limpede al Germaniei post-68iste. În care franchețea lui Luther s-a încrucișat

\footnotetext{
${ }^{1}$ Folosesc cei doi termeni consacrați în universul poetic stănescian, adaptat contextului. Prin cuvînt, în acest context, înțeleg aceea entitate lexicală autonomă, unitară care în cadrul unui sistem lingvistic poate fi perceput ca întrunire bipolară de semnificant și semnificat. Prin necuvînt înțeleg acele unități lexicale care doar din perspectiva unui alt sistem lingvistic capătă referențialitate.

${ }^{2}$ Folosesc termenul de hipersemn cu sensul de text construit prin transformarea sau imitarea altui text (Nagy, 2015; Corti, 1981).
} 


\begin{tabular}{llll}
\hline Nivelurile lecturii & Referent & Exemple din roman \\
\hline $\begin{array}{l}\text { 1. } \begin{array}{l}\text { Nivel textual } \\
\text { inter-cultural }\end{array} \\
\text { Cultura lecturii }\end{array}$ & $\begin{array}{l}\text { „Monty Pyton-ul brașovean” (9) , ,...e clar, ca pe } \\
\text { orice Scufță Roșie, te atrage în primul rînd lupu” } \\
(18 \mathrm{p})\end{array}$ \\
\hline $\begin{array}{l}\text { 2. Nivelul } \\
\text { inter-discursului }\end{array}$ & $\begin{array}{l}\text { Un enunț care are } \\
\text { marginile populate } \\
\text { de alte enunțuri }\end{array}$ & $\begin{array}{l}\text { „Așa, de la Arad, horonka-troste o de-asta de-a lui, de stă mîța-n coadă” } \\
(89)\end{array}$ \\
\hline 3. & Translingvistic & $\begin{array}{l}\text { „Afon, da, áfonya, cum ar spune Melinda. Știi ce } \\
\text { înseamnă afonya? Afine!” (15) }\end{array}$
\end{tabular}

Tabela 1: Nivelurile constituirii portretului bilingv, bicultural

cu icnetele viscerale ale lui Janice Jopplin și marxismul sexual al Rotte Armee Faktion.” (16); „In care nu știi cine șa-a-de, cum cînta măscăriciul ăla slinos, în cenaclul Grasului, depe vremuri.” (10); „Dar mafioții sînt și ei oameni. De fapt, peste tot același lucru, legea lui Ohm: fii om cu mine, ca să fu om cu tine” (20); „Nebunel și trîntește o de-asta de-a lui, de stă mîța-n coadă." (38).

Cel de al doilea nivel, este nivelul interdiscursului prin care înțelegem un enunț care are marginile populate de alte enunțuri (terminologia lui Foucault, în Dospinescu, 2008), o alternativă a intertextualității, o interacțiune „a două sau mai multe discursuri a căror configurare originară nu poate fi reconstituită, dar favorizează producerea de semnificații implicite” (Nagy, 2015, p. 194). Interdiscursul pregătește elementele intradiscursului ca topos al desfăşurării regulilor, care urmează logica limbii de bază, fără susținerea altor elemente cu scopul de a produce înțelegerea (Nagy, 2015). Nivelul intralingvistic al textului în acest caz aduce elementele și situațiile translingvistice de comunicare, bazate pe ruptura coerenței unui sistem lingvistic, prin activarea complementară a limbilor. Iată cîteva exemple ilustrative din textul romanului:

„...căutînd prin brelocuri cu laternă, unghiere, calendare, iconițe 3D, maimuțe care țipă și cărora li se luminează ochii cînd apeși pe urechi, teancuri de post-it și mai ales, da, mai ales, über alles, überhaupt, pixuri. Zeci si zeci." (7)

„OK. Pe tine te interesează Vlad. Ba da. Stop bullshiting me, nu-mi mai turan despre dinamica mentalităților, rețele sociale, contracultura în vremea lui Ceauşescu.” (9)

Romanul debutează cu vocea eului narator, în drum spre locul acțiunii. Introducerea în locul și atmosfera acțiunii se realizează prin conturarea unui spatiu multilingv: limba dominantă (de bază) a comunicării e cea română, însă în funcție de situatie, se apelează la germană, maghiară, engleză. Atmosfera sufocantă a trenului redă un mod de a percepe haosul balcanic de către un străin, avînd perspectiva receptorului din afară care ajunge treptat în T,inutul Secuilor și devine actorul cîmpului relațional. Atmosfera din tren este redată sugestiv: „Urmărește-mă cu atenție, schau mal, stai pe jumătate adormit, pe trei sferturi, quatsch, nici eu nu știu cît de...” (7); „...Și aşa am ajuns din nou în România. De fapt, în Szeklerland, Szekelyföld, Țara Secuilor." (18).

Cel de-al treilea nivel textual reprezintă prin organizarea ei lingvistică nivelul translingvistic care capătă diferite forme de realizare și vizează diferitele unităţi, niveluri ale limbii. Apar în text:

a. situații translingvistice cu accent interferențial marcat chiar și în textul romanului:

„-Igen, nemzetkozi, internațional. A fost la Ólimpiade și așa...campiona mondial...la, no, cum ii spune?...asztalitenisz" (24)

„...A fugit undeva...” (27)

b. situaţii translingvistice cu lexem-străin adaptat:

„Se pare că in toată povestea e implicat și un Rumäniendeutscher de-al tău, un german din România." (19) 
„să facă buliparty” (29)

„Dar pentru moment toate chestiile astea din capul meu aveau să intre în stand-by” (44)

c. situații translingvistice prin inserție de cuvinte, structuri:

"Afon, da, áfonya, cum ar spune Melinda. Știi ce înseamnă afonya? Afine!" (15)

"A fost echt, a fost de-adevărat" (14)

„Așa. No, el e...Si el e puszipajtas, se pupă-n bot cu Marin Manta." (29)

„Ceea ce ne invață pastorul Astner la catehism nu e doar un Witz, un banc.” (40)

„Ei bine, predestinare spun, cînd mă uit înapoi. Fiindcă, ach, du, Karina, süßes Kind, nu era oare groapa din mijlocul casei un semn, o prefigurare?” (41)

d. situații de valorificare a elementelor vorbirii orale dintr-o altă limbă:

„Ei bine, într-un fel, fința aceea de abur, nimfa-vînzător ambulant, naiada-pusher, $m$-a condus la ea. Ceea ce înseamnă că e OK, că aşa trebuia să fie. Musai. A szerelemnek, cred că se spune. A szerelem. La Melinda." (8)

"In care nu știi ci-i-neşa-a-ade...” (41)

„Evident că s-a precipitat spre mine:

- Ioi, auch, scuze, scuze, bocs!" (48)

În cazul acestor treceri, transpuneri inter-lingvistice, autorul este atent și la receptorii săi, la constituirea înțelegerii chiar și în cazul unui vorbitor monolingv sau a acelora pentru care necunoașterea anumitor cuvinte din limba celuilalt ar putea provoca dificultăți de înțelegere. Soluția găsită pentru rezolvarea acestor situații constă în repetarea sau reformularea idelor și în limba de bază a comunicării. Iată cîteva exemple din roman: „Eintritt streng verboten. Intrarea strict interzisă. Acolo nu avea voie nimeni, în afara personajului” (42); „Die Fresse des Mörders. Mutra asasinului” (13).

În conturarea portretelor, dincolo de tehnicile „du-te-vino” dintre două sau trei limbi, apar scene prin care se conturează indirect alte elemente ale conduitei verbale. Sînt ilustrative din acest punct de vedere situațiile de comunicare prin care putem observa cum vorbitorii îşi compensează hiatusul lexical sau nesiguranța exprimării, prin strategii diferite de căutare a cuvîntului potrivit, cum ar fi: descrierile explicative introduse cu scopul de a se face de înțeles sau valorificarea din repertoriul lingvistic al cuvintelor, expresiilor, trecînd peste cadrul oferit de un sistem lingvistic.

În discuția cu Melinda, V Lupu:

„- E mare bai cu fiul, știi, cu fuul...

- Al cuifiu?

- A lui omul ăsta.

- Despre ful lui Manta nu aveam habar. Deşi a rezultat că ar fi trebuit să am.” (26)

”- Asta și fiindcă el nu este, no, în țară. Se pare că a fugit úndeva la Karibik, no ceva trópusi sziget, no.

- Insulă tropicală? Am ridicat și mai tare din sprîncene.

- Igaz, așa, trópicala, și de acolo dă din cînd în cînd cîte o, asta, ca la revoluție, cum se spune?, proclamație, no, așa..." (27)

„Nu intră la capul lui ce important este asta, az erdö, pădurea, plămîn prin care respiră az bolygó, planeta..." (28)

Alături de vorbirea spontană a personajelor, apare din cînd în cînd și vocea naratorului, și reflecțiile acestuia asupra modului de exprimare a personajelor: „Ach, cît era de dulce amestecul de accent secuiesc și accent ardelenesc al valahilor, al Bloch-ilor, cum ar fi spus strămoşii mei saşi...” (28) 


\section{Un alt fel de portret... în oglindă}

Plăcerea lecturii acestui roman rezultă în primul rînd din rupuri şi contopiri ale alterităţii, prin redistribuirea limbajului. Asistăm la un fel „de a găuri discursul fără a-l face lipsit de sens” (Barthes, 1994, p. 15), căci rupturile lingvistice în acest text sînt supravegheate tocmai pentru a reda manifestările spontane ale vorbitorilor bi(multi)lingvi şi bi(multi)culturali. Astfel, putem percepe amprenta socio-lingvistică a conduitei verbale, realizată prin reelaborarea stilistică a structurii sintagmatice. Asemenea portret, aparținînd aceluiași topos socio-cultural și lingvistic, apare într-un alt roman apărut în același an cu opera lui Caius Dobrescu. Este vorba de caracterizarea indirectă a conduitei bilingve în romanul lui Gábor, Vida Egy dadogás története [Istorisirea unei bîlbîieli]. În această scriere se conturează portretul invers al conduitei verbale bilingve, căci aici asistăm nu atît la valorificarea, cît mai degrabă la substituirea, chiar refularea repertoriilor lingvistice. Este vorba de portretul lui Fjodor bácsi (nea, nenea Fjodor) un maghiar românizat.

„...Nea Fjodor se considera maghiar, dar știa mai bine româneşte, vorbea o limbă mixtă ciudată, care mai tîrziu îmi reevoca ceangăii, deși intonația lui maghiară era de pe cîmpie, accentul lui românesc nu era al locului, ci acel vorbit de olteni, muzicalitea românească și duritatea ungurească erau la el intr-o opoziție ciudată. De la noi întotdeauna cerea scuze că nu știe bine ungurește. Acest lucru pe mine mă deranja, căci am avut impresia că vorbeşte foarte bine, dar nu prea vrea să vorbească."

(Vida, 2017, p. 185)

Portretul de față ne oferă o dimensiune intrinsecă a conduitei verbale, care, în opoziție cu activarea liberă, eterogenă și complementară a limbilor conturate în cazul personajelor lui Caius Dobrescu aduce imaginea unei vitalități lingvistice închise în cadranele unui control restrictiv.

\section{Concluzii}

În acest studiu, concetrîndu-mă asupra lecturii universului artistic creat în romanul Moarte în ținutul secuilor, de Caius Dobrescu, am încercat să urmăresc modul cum lingvistica textului devine un constituent al arhitecturii creației. Desigur, acest mod de re-lectură presupune urmărirea modului cum procedeele inventariate mai sus vor fi sau nu preluate și continuate în celelalte romane ale acestui ciclu. Cert este că în romanul lecturat, asistăm prin rupturile interlingvistice și contopirea alterității la redistribuirea limbii. Autorul creează un hipersemn constituit dintr-un cod idiolectal specific, translingvistic și transfrastic, prin care oferă posibilitatea interpretării metasemantice. Expresivitatea rezultă din valorificarea vitalității îmbinărilor translingvistice.

Prin aceste treceri, prin acest du-te-vino între limbi, funcția referențială a limbii este investit cu alte valențe, căpătînd prin sensurile de suprafață și cele subiacente funcții culturale și interculturale. În acest context sînt prezentate în acest roman portrete, locuri, spații, cadre, fețe care împreună redau ceva din strădania căutării cuvîntului potrivit prin raportare la peisajul și conduita (multi)lingvă specifică unui spațiu socio-cultural bine determinat.

\section{Bibliografie}

Auer, P. (ed.) (1998). Code-switching in Conversation: Language, Interaction and Identity, Routledge, London.

Bartha, Cs. (1999). A kétnyelvüség alapkérdései [Fundamentele bilingvismului], Nemzeti Tankönyvkiadó, Budapest.

Barthes, R. (1994). Plăcerea textului, Echinox, Cluj Napoca

Benö, A. (2008). Kontaktológia. A nyelvi kapcsolatok alapfogalmai [Contactologie. Fundamentele interdependențelor lingvistice], Egyetemi Műhely, Kolozsvár.

Canagarajah, S. (2011). Codemeshing in academic writing: Identifying teachable strategies of translanguaging, în "The Modern Language Journal", 95 (3), p. 401-417, Crossref.

Cenoz, J. \& Gorter, D. (2017). Translanguaging as a pedagogical tool in multilingual education, în Cenoz, J., Gorter, D. \& May, S. (eds), Language awareness and multilingualism, Springer International Publishing, Dordrecht, p. 309-321, Crossref. 
Cornea, P. (1998). Introducere în teoria lecturii, Polirom, Iași.

Corti, M. (1981). Principiile comunicării literare, Editura Univers, București.

Coșeriu, E. (2009). Omul și limbajul său, Editura Universității „Alexandru Ioan Cuza”, Iași.

Coșeriu, E. (2013). Lingvistica textului. O introducere în hermeneutica sensului, Editura Universității „Alexandru Ioan Cuza”, Iași.

Dobrescu, C. (2017). Moarte în ținutul secuilor, Crime Scene Press, București.

Dospinescu, V. (2008). Eugen Coșeriu și lingvistica textului, în „Limba română”, 17 (5-6).

Ferguson, Ch. (1959). Diglossia, în Bratt Paulston, C. \& Tucker, R.G. (eds), Sociolinguistics. The essential readings, Blackwell Publishing, Malden (MA), p. 345-358.

Fishman, J. (1970). Sociolinguistics: a brief introduction, Newbury House, Rowley (MA).

Fishman, J. (2000). Bilingualism with and without diglossia; diglossia with and without bilingualism, în Wei, L. (ed.), The bilingualism reader. Routledge, London - New York, p. 81-88.

Gafaranga, J. \& Torras i Calvo, M.-C. (2001). Language versus medium in the study of bilingual conversation, în „International Journal of Bilingualism", 5 (2), p. 195-219, Crossref.

García, O. \& Wei, L. (2014). Translanguaging: language, bilingualism and education, Palgrave Macmillan, New York, Crossref.

Gorter, D. \& Cenoz, J. (2015). Translanguaging and linguistic landscapes, în „Linguistic Landscape”, 1 (1), p. 54-74, Crossref.

Gumperz, J.J. (1982). Discourse strategies, Cambridge University Press, Cambridge, Crossref.

Holmes, J. \& Wilson, N. (2017). An Introduction in Sociolingvistics ( $5^{\text {th }}$ edition), Routledge, London - New York.

Nagy, R. (2015). Dicționar de analiză a discursului, Institutul European, Iași.

Navracsics, J. (2000). A kétnyelvü gyermek [Copilul bilingv], Corvina, Budapesta.

Tódor, E.-M. (coord.), Bartha, K., Benő, A., Dégi, Zs., Magyari, S. \& Tankó, E. (2019). Alkalmazott nyelvészeti szótár (A kétés többnyelvüség alapfogalmai) [Dicționar de lingvistică aplicată (Conceptele fundamentale ale bi- și multilingvismului)], Presa Universitară Clujeană, Cluj-Napoca.

Vida, G. (2017). Egy dadogás története [Istoria unei bîlbîieli], Magvető, Budapesta.

Vlad, C. (2000). Textul aisberg. Elemente de teorie şi analiză, Casa Cărții de Ştiință, Cluj-Napoca.

Wei, Li (2005). 'How can I tell?'. Towards a common sense explanation of conversational code-switching, în "Journal of Pragmatics”, 37 (3), p. 375-389, Crossref.

Wei, Li (2011). Moment analysis and translanguaging space. Discursive construction of identities by multilingual Chinese youth in Britain, în „Journal of Pragmatics”, 42 (5), p. 1222-1235, Crossref.

Wei, L. (2018). Translanguaging as a Practical Theory of Language, în „Applied Linguistics”, 39 (1), p. 9-30, Crossref. 